\title{
The Language of Food: A Review of the 2009 Oxford Symposium on Food and Cookery
}

Máirtín Mac Con lomaire

Technological University Dublin, mairtin.macconiomaire@tudublin.ie

Follow this and additional works at: https://arrow.tudublin.ie/tfschafart

Part of the Arts and Humanities Commons, and the Food Studies Commons

\section{Recommended Citation}

Mac Con lomaire, M. (2009). The Language of Food: A Review of the 2009 Oxford Symposium on Food and Cookery. Journal of Culinary Science and Technology, Vol. 7, No.2-3, pp.211-217, DOI: 10.21427/ $\mathrm{d} 7 \mathrm{mb} 4 \mathrm{r}$

This Article is brought to you for free and open access by the School of Culinary Arts and Food Technology at ARROW@TU Dublin. It has been accepted for inclusion in Articles by an authorized administrator of ARROW@TU Dublin. For more information, please contact arrow.admin@tudublin.ie, aisling.coyne@tudublin.ie, gerard.connolly@tudublin.ie.

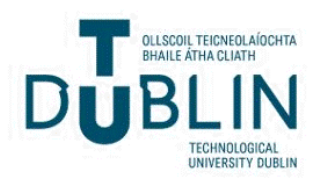




\section{The Language of Food: A Review of the 2009 Oxford Symposium on Food and Cookery}

\section{Máirtín Mac Con Iomaire Ph.D., Dublin Institute of Technology}

The theme for this year's Oxford Symposium on Food and Cookery, held in St. Catherine's College, Oxford was food and language. Humans are known generally as language animals, and many believe we became human by cooking our food. Gastronomy has been described by Theodore Zeldin as the method of using food in making happiness. Does the preparation, serving and consumption of food act as a coded language between host and guest, indicating love, affection or even disrespect; power and social status; nationality and religion? Recipes are seen by many food historians and cultural linguists as windows on the world, but is any language's vocabulary rich enough or precise enough to describe the sensations of taste, sight, smell, texture and other physical aspects of food adequately? Might pictures perform some of this task better than any words - or do they emphasize presentation at the expense of taste and texture? When a number of professional chefs, restaurant customers and leading food writers eat the same food and drink the same wine, do they taste the same flavors? Can they describe their experiences? In the age of blogs and the internet, is there anyone editing, policing, or critiquing the cyber food writers? How far has the language of food changed over time? Can a recipe be copyrighted? Over two hundred leading food writers, historians, chefs, anthropologists, linguists, scientists, students and general food enthusiasts contributed to the debate on these topics over a weekend of study and conviviality.

The keynote address by Simon Schama, 'Mouthing Off: Reflections on Eating and Uttering' reminded the audience that restaurant critics are seldom cooks and questioned whether we can actually adequately write about food, likening it to both music and sex, both of which have an extensive literature. Do we have sufficient language to fully describe either, since exact repetition seldom happens in food, music or sex! Len Fisher

quoted the philosopher Thomas Nagel's notion that subjective experiences are unique to 
each of us. Fisher points out that this is not just a matter of philosophy, since scientifically each individual actually tastes the same shared meal differently. In particular, humans have different detection thresholds for the vast array of food aromas that contribute so much to our enjoyment. Selective anosmia, the inability to detect a particular odor, according to Fisher is a real issue. Some $30 \%$ of humans cannot smell androstenone, which is the odor component in truffles. Thirty-six percent of the population is anosmic for isobutyradehyde, found in white bread, beer and chocolate, and $7 \%$ are virtually anosmic to trimethylamine, a compound whose presence is one of the first indicators that a fish is not totally fresh. Fisher's paper 'How do you describe a champagne jelly?' argues that food writers have two basic approaches to describe their experiences to their readers. One is to attempt to describe the internal experience of the writer, whilst the other is to communicate an expectation to the reader, an approach Fisher favors. Scientists have found that the language used on a menu can influence the diner's actual perception of flavor. When Heston Blumenthal changed the description of his 'Crab Flavored Ice-cream' in his restaurant The Fat Duck, and renamed it 'Frozen Crab Bisque', customers found that it tasted different, less sweet, although the recipe remained exactly the same.

The power of language applies equally to wine. Patrick Baude's paper titiled 'The Hermeneutics of Wine Criticism' argued that wine critics do not write about wine as such, they are writing about the good life to which wine may be a tool. Baude identifies three main schools in wine writing: (1) consumerist; (2) the school of terroir; and (3) admirers of the wine maker. He then suggests that the three schools correspond to the following important movements in critical theory: (1) the new criticism; (2) critical social theory; and (3) the auteur analysis of film. Since wine is a complex agricultural product, manufactured by a large team and many mechanical processes, Baude asks that if we think of the process as "art" to criticize, who do we call the "artist"? Drawing an analogy with a motion picture film, which also requires a large team and many mechanical and administrative processes, the auteur theory conceives of the film as the product of the director, so Baude argues that the wine equivalent is the owner / wine maker such as Robert Mondavi, Piero Antinori, George Duboeuf or fitting the film analogy, Francis 
Ford Coppola, who is the owner of the Rubicon winery in the Napa Valley and could be argued to have 'directed' the wine. Symposiasts were asked in the original call for papers to consider whether the vocabulary of the wine taster was more precise than that used to describe food. Many of the "descriptors" used in wine-tasting - "tarry," "gooseberries," "vanilla," "yeasty," and even "bananas" and "bubblegum", often seem metaphorical, flowery and imprecise to the reader or listener, yet have been proven to be appropriate to the chemical compounds actually present in the wine.

Can the language of specific cuisines be adequately translated into other languages? Kimiko Barber suggests Japanese food is different than western food and therefore its food experiences and sensations are best described in its own language. Barber notes that the Japanese language contains more onomatopoeic and mimetic words, especially food related words, than English. The Japanese words to describe what we in English call "crispy" include shaku-shaku, bari-bari, kori-kori, pari-pari or pori-pori depending on the context. To describe the English work "crunchy" the Japanese have kari-kari, garigari, bari-bari, bori-bori, and boro-boro to name but a few. It is difficult to adequately translate the Japanese word "shun" (literally season) which means the particular moment when a food is at its best, be it a fleeting moment, a week, or a few months. There are many proverbs, poems and haikus that relate to "shun"; one speaks of when the cherry blossom is most beautiful, it is the best time to taste sea-bream. Elizabeth Andoh suggests that in their literal translations, some Japanese menus could be mistaken for poetry. Dishes with names such as tsuki mi ("moon viewing"), shigure ("autumnal rains"), and momiji oroshi ("crushed red maples"), she proposes, read as an ode to autumn. Andoh argues that "poetic names evoke special images to the educated Japanese palate, while conveying specific information about the food." In Japan, a person who has been brought up in a wealthy and comfortable home is described as "someone who has picked up nothing heavier than a pair of chopsticks." How does this compare with the western saying "born with a silver spoon in his mouth?" Is it more nuanced?

Barber outlines five principles of wa-shoku or "Japanese style cuisine" which includes five colours, five tastes, five cooking methods, five senses and five spiritual outlooks. 
Rice, she suggests, is the soul of Japan. The word "gohan", for cooked rice, also means meal. In the written language, among the food related Chinese characters, the ideogram radical for rice appears in 128 characters, which is more than any other radical. A Japanese proverb describes a close and trusted friend as one who has "shared the rice cooked in the same pot." Food, however, concludes Baber, is like music, it transcends language barriers.

The panel discussing "Food and the Book" included food editors Jill Norman (Elizabeth David, Penguin), Judith Jones (Julia Child, Knopf), Susan Friedland (HarperCollins) and cookbook historian Barbara Ketchum Wheaton. The changing world of publishing was discussed with the disappearing role of copy editors, recipe testers, and proof-readers among some publishing houses lamented. Some writers such as M.F.K. Fisher were identified as having matchless poetic talent, but some food commentary, particularly on the internet, was derided. One such internet example was given: "this is the very best recipe I have seen for bread. It is so good that I may try to cook it sometime." Friedland noted that by following many recipes even in published cookbooks, if you don't know how to cook, you could ruin really good food! She noted that in commercial publishing, one needs to watch the bottom line and pointed out that best selling books such as 365 ways to cook a Hamburger were the "pornography that supported the poetry" in HarperCollins. It was argued that the personality of the author needs to be visible in cookbooks, and the reader needs to believe and trust them. Claudia Roden, Madhur Jaffrey and Richard Olney were given as examples of writers who all had distinctive voices, sufficient language skills and used food to reconnect with the past.

Darra Goldstein pointed out that discourse can be defined as language in use, which may be written, spoken or signed. She started her presentation of food in pictures and photographs with an image that, to an astronomer would represent the moon; to a mathematician would represent an ellipse; but that the food-centred audience clearly interpreted as an egg. One image by the artist Sarah Lucas showing a girl wearing a tshirt with two soft fried eggs positioned to suggest lactating breasts, was interpreted as symbolizing the artist's uncertain relationship with her own fertility. The debate of food 
and art however remains unresolved. Andy Warhol's picture of a can of Campbell's soup can be art, but it seems that the contents of the can cannot!

David Sutton discussed the difference between the coarse Anglo-Saxon origins of the words cow, sheep, pig, or oxtail, compared with the refined Norman origins of beef, mutton, and pork. The Anglo-Saxons produced the food, but he suggests their Norman masters turned it into cuisine. He also discussed the numerous food related proverbs found in English, particularly ones about butter, herrings, geese and garlic: 'Garlic makes a man wink, drink and stink', 'fine words butter no parsnips', 'Money like dung does no good till it's spread'. The Turkish proverb 'You don't mix meat with milk', according to Aylin Öney Tan, stems from the kosher tradition of the Sephardic Jews that were driven from Spain in the same year as Columbus's journey to the new world (1492) and migrated mostly to the Ottoman Empire, bringing their cuisine with them. Tan suggest that traces of the Sephardic Jewish influences still remain in Turkish cuisine, highlighting the similarities between Turkish Börekitas and Spanish Empanadas, and noting also that Turkish kosher cheese is nearly identical in flavor to Manchego. The language of food in the bible was discussed in a number of papers. The Book of Leviticus identifies foods that are considered unclean or unsafe to eat. Similar advice comes from many forms. One of the proverbs quoted by Sutton was 'Better no pies than pies made with scabby hands'. A more recent use of verse to promote food safety was sung to the air of the Bee Gees "Staying Alive" on the Friday night at a post dinner food poetry and song session. The chorus went "I don't want hepatitis or gastroenteritis, I'm just staying alive!"

The use of linguistics to reconstruct food history was discussed by Birgit Ricquier and Koen Bostoen. Their work using linguistics to reconstruct the culinary traditions of early Bantu speech communities in Central and Southern Africa was highlighted, pointing out that where no written evidence exists, and where the archeological record is limited, that linguistics can shed light on otherwise hidden stages of human history. For example, by reconstructing the verb *-bu\$mb- in Proto-Bantu with the meaning "to bake in hot ashes", Ricquier and Bostoen imply that baking food in the ashes of the fire was one of the cooking techniques used by the earliest Bantu speech communities. A more current method of preserving hidden culinary history was promoted by Máirtín Mac Con Iomaire 
whose paper championed the wider use of oral history among culinary historians to gather and preserve the memories and life experiences of chefs, waiters, restaurateurs and diners before it perishes with the informants. Despite growing culinary collections in libraries such as the Schlesinger in Harvard, New York Public Library, the University of Adelaide, or Oxford Brookes, neither houses an oral history culinary archive. The devastation of Hurricane Katrina in 2005 sparked a number of food related oral history projects in New Orleans and along the Gulf Coast, but the author suggests that historians act now rather than fear the obituary page.

Rachel Laudan made ten suggestions in her paper on what culinary historians can learn from linguists. She began by noting that most linguistic scholars estimate that there are somewhere between 4,000 and 5,000 living languages in the world, all of which have been named. Despite all the outpouring of cookbooks, handbooks and encyclopedias of food, Laudan suggests that we have no idea about how many cuisines there are in the world and proposes beginning an inventory of cuisines, both that exist today, and that existed in the past. Some criteria needs to be agreed for deciding when two cuisines are really different, not just variants. Like dialects in language, some differences in cuisines are merely regional variations. Giving as an example a Mexican meal prepared for the Oxford symposiasts over a decade ago, where only three members of the 200 guests had previously encountered maize tortillas, Laudan suggests that "when a group of cooks and diners do not recognize the ingredients, nor understand the rules for combining them, nor have any idea of the context in which certain dishes would be used, nor the meaning attached to them, then he or she does not understand the cuisine." It is clearly a different cuisine. Cuisines should be organized into families and sub-families. Since most people in the world are bi-lingual, Laudan asks whether it is possible to bi-cuisinal? How many people in the world are bi-cuisinal? Further suggestions were that the expansion and contraction of cuisines should be traced. The death and birth of cuisines should also be investigated. The role of loan dishes and ingredients as used in fusion cuisine should be investigated. She concluded by asking whether there were Creole cuisines in the same sense as Creole languages? Is it possible to reconstruct a dead cuisine? And finally, is it possible to disentangle cuisines form races, nations and regions? 
Paul Freedman's paper "The rhetoric of American menus and the use of French" discusses the changing fashions of menu rhetoric and in particular explores the use of French in American restaurant menus in the mid $19^{\text {th }}$ century "to burnish the sophistication of what was essentially derivative of Victorian cuisine." The menu of one of America's first French restaurants "Delmonico's" which opened in New York in 1832, contained classic French dishes such as Saumon au beurre de Montpellier alongside dishes such as Fillet de Boeuf à la Pocahontas, which were clearly not classical. He points out that the language of menus, beyond conveying information, creates a sense of excitement and encourages an impression of originality over what is essentially a routine activity. He debates the use of French or "Franglaise" (French and English) and warns restaurateurs that to flatter the customer, or at least not to embarrass them into helplessly petitioning for enlightenment, the menu needs to "not only subtly entice but at the same time to reassure and conform to expectations." Moving to the language of menus in modern day Paris, Carole Faivre's paper "Sex, food and Valentines Day: Language of Food - Language of Love" provides a linguistic analyses of St Valentines Day menus in a series of thirty Parisian restaurants. Faivre suggests that "the names of dishes on Valentine menus reinforce the feeling of love on the romantic side and will contribute to the anticipation of the night to come on the erotic side." She concludes that food and love are strongly entwined, and that naming a dish suggestively to entertain guests on a themed night also gives us a snapshot of the representations associated between food and love in modern day Paris.

Moving back to America, Cathy K. Kaufman's paper "Language, Recipes and Dishes" discusses the differences between copyright and patents, and traces various legal cases in which copyright for certain dishes were unsuccessfully sought. Individual recipes are not copyrightable regardless of the creativity of the dish that results, yet a collection of recipes in a cookbook can be copyrighted even if the recipes themselves are rehashed versions of well known dishes. While the owner of a copyright can prevent someone from copying their work, they cannot stop someone from using an identical work that was developed independently. Patents, however, prevent anyone from using the patented idea or process, regardless of independent development or ignorance of the original 
patented idea. Kaufman notes that Homoro Cantu, the noted molecular gastronomist from the Chicago restaurant "Moto" was granted one of the most notable culinary patents for inventing a "system and methods for preparing substitute food items." By adapting a printer to print paper made from edible starches with flavoured edible inks, Cantu might serve diners in Moto "a bite size sheet of tapioca decorated with a picture of sushi which tastes like the image." Raymond Blanc, chef / proprietor at Le Manoir de Quatre Saison, sought no patent for his method of producing a tomato consommé using a jelly bag. Not only did he serve the dish as a course in the Saturday night Symposium banquet themed "The raw and the cooked", but he had the recipe included on the back of the menu for diners to freely enjoy and further disseminate.

Overall there were forty two papers delivered at the 2009 symposium, along with keynote addresses, plenary sessions, artistic performances and spectacular dining. Next year's Symposium will take place on the 9-11 July 2010 and the theme is Cured, Smoked and Fermented Foods. Further information is available (www.oxfordsymposium.org.uk). Proceedings from the Symposium are published annually by Prospect Books (www.prospectbooks.co.uk). 